\title{
SYNERGISTIC ACTION OF PROLACTIN WITH HCG ON RAT VENTRAL PROSTATE
}

\author{
B. DATTATREYMURTY, V. P. RAGHAVAN, T. V. PURANDARE, \\ A. R. SHETH AND SHANTA S. RAO \\ Institute for Research in Reproduction (I.C.M.R.), Parel, Bombay 400012, India
}

(Received 14th Fanuary 1975)

The increase in the weights of the ventral prostate and other accessory sex organs of the immature rat has been employed as an end point for estimating the biological potency of preparations of LH and HCG (Greep et al., 1941, 1942; Diczfalusy \& Loraine, 1955). Several investigators have claimed that prolactin alone or synergistically with androgens has a role in the growth of the male accessory sex organs (Segaloff et al., 1956; Chase et al., 1957; Antliff et al., 1960; Bengmark \& Hesselsjo, 1963, 1964; Okamoto et al., 1967; Dorfman, 1972; Negro-Vilar et al., 1973). In these studies, large amounts of prolactin were used, and the possible presence of small amounts of contaminating $\mathrm{LH}$ could not be ruled out. It was therefore of interest to re-examine the effects of prolactin alone or with HCG on the growth of the male accessory sex glands of the rat.

Biological and bioimmunological experiments were carried out (see Table 1) with 20- to 23-day-old immature male rats of the Holtzman strain. The HCG (Ayerst Laboratories, U.S.A.) and ovine prolactin (NIH-P-S10) were administered subcutaneously to rats once a day on 3 consecutive days, at approximately 24-hr intervals while control animals received saline or normal rabbit serum. In the bioimmunological experiments, one group of animals received a mixture of ovine prolactin and the antiserum to ovine prolactin, which was incubated at $37^{\circ} \mathrm{C}$ for $1 \frac{1}{2} \mathrm{hr}$. The preparation and specificity of this antiserum has been described elsewhere (Purandare et al., 1975; Thakur et al., 1975). On the 4 th day of the experiment the rats were weighed and killed. Statistical evaluation of the results was carried out using Student's $t$ test.

The results indicated in Table 1 show that administration of $20 \mu \mathrm{g}$ ovine prolactin +1.0 i.u. HCG caused a significantly greater increase $(0.001<P<0.01)$ in the weight of the ventral prostate than did HCG alone, but no significant increases occurred in the weights of the testes, dorsolateral prostate and seminal vesicles. When $20 \mu \mathrm{g}$ ovine prolactin were administered alone, there were no changes in the organ weights. There was no further increase in the weight of the ventral prostate when $20 \mu \mathrm{g}$ ovine prolactin $+2 \cdot 0$ i.u. HCG were given. When the antiserum to ovine prolactin was administered with ovine prolactin, the stimulation of the ventral prostate brought about by prolactin + HCG was suppressed (Table 1). These results confirm that the effect of prolactin in potentiating the action of HCG on the ventral prostate is not due to its contamination with $\mathrm{LH}$. 
Table 1. The effect of ovine prolactin alone or with HCG on the weights $(\mathrm{mg} / 100 \mathrm{~g}$ body $\mathrm{wt}$ ) of the testes and accessory sex glands of immature male rats

\begin{tabular}{|c|c|c|c|c|}
\hline Treatment & Testes & Ventral prostate & $\begin{array}{c}\text { Dorso- } \\
\text { lateral prostate }\end{array}$ & $\begin{array}{l}\text { Seminal } \\
\text { vesicles }\end{array}$ \\
\hline Saline (controls) & $\begin{array}{c}610 \cdot 55 \pm 23 \cdot 41^{2} \\
(9)\end{array}$ & $47 \cdot 40 \pm 3 \cdot 81^{\circ}$ & $\frac{62 \cdot 79 \pm 3 \cdot 75^{a}}{(9)}$ & $\begin{array}{c}21 \cdot 34 \pm(9) \\
(9)^{2}\end{array}$ \\
\hline HCG (1.0 i.u.) & $\begin{array}{c}674 \cdot 08 \pm 30 \cdot 70 \\
(10)\end{array}$ & $\begin{array}{c}79 \cdot 96 \pm 4 \cdot 13^{b} \\
(10)\end{array}$ & $\begin{array}{c}85 \cdot 13 \pm 3 \cdot 32^{b} \\
(10)\end{array}$ & $\begin{array}{l}33 \cdot 19 \pm 3 \cdot 48^{b} \\
(10)\end{array}$ \\
\hline $\begin{array}{l}\text { HCG }(1.0 \text { i.u. })+\text { ovine } \\
\text { prolactin }(20 \mu \mathrm{g})\end{array}$ & 707-15 $\frac{ \pm}{(7)} 30 \cdot 22$ & $\frac{102 \cdot 63+4 \cdot 61^{c}}{(7)}$ & $91 \cdot 32+\frac{5 \cdot 97^{b}}{(7)}$ & $32 \cdot 83+\frac{2 \cdot 51^{6}}{(7)}$ \\
\hline HCG (2.0 i.u.) & $\begin{array}{c}725 \cdot 92 \pm 28 \cdot 76^{b} \\
(10)\end{array}$ & $\begin{array}{c}96 \cdot 90 \pm 5 \cdot 72^{d} \\
(10)\end{array}$ & $\begin{array}{c}93.99 \pm 4.05^{b} \\
(10)\end{array}$ & $\begin{array}{c}42 \cdot 25 \pm 3 \cdot 41^{\circ} \\
(10)\end{array}$ \\
\hline $\begin{array}{l}\text { HCG }(2.0 \text { i.u. })+\text { ovine } \\
\text { prolactin }(20 \mu \mathrm{g})\end{array}$ & $714 \cdot 11 \pm 22 \cdot 48$ & $\begin{array}{c}94 \cdot 53 \pm 4 \cdot 77^{d} \\
(11)\end{array}$ & $\begin{array}{c}93.97 \pm 4.97^{b} \\
(10)\end{array}$ & $\begin{array}{l}42 \cdot 87 \pm 3 \cdot 67 \\
(10)\end{array}$ \\
\hline Saline+NRS (controls) & $\underset{(9)}{605 \cdot 27 \pm 17 \cdot 50}$ & ${ }_{(9)}^{50 \cdot 32 \pm 1 \cdot 44^{a}}$ & $\frac{64 \cdot 79 \pm 3 \cdot 10^{n}}{(8)}$ & $\underset{(9)}{20.96 \pm 0.72^{2}}$ \\
\hline $\begin{array}{l}\text { Ovine prolactin }(20 \mu \mathrm{g}) \\
+ \text { NRS }\end{array}$ & $\begin{array}{c}554 \cdot 90 \pm 20 \cdot 72 \\
(10)\end{array}$ & $\begin{array}{c}45 \cdot 13 \pm 2 \cdot 23^{2} \\
(10)\end{array}$ & ${ }_{(1 \overline{0})}^{64.92 \pm 2 \cdot 55^{a}}$ & $\begin{array}{l}18 \cdot 63 \pm 0.65^{\circ} \\
(10)\end{array}$ \\
\hline HCG $(0.75$ i.u. $)+N R S$ & $\underset{(9)}{666 \cdot 17 \pm 35 \cdot 01}$ & $\begin{array}{c}74 \cdot 07 \pm 1 \cdot 28^{b} \\
(10)\end{array}$ & ${ }_{(9)}^{83.04 \pm 3.64^{\mathrm{e}}}$ & $\begin{array}{c}33.43 \pm 1.05^{\circ} \\
(9)\end{array}$ \\
\hline $\begin{array}{l}\text { HCG }(0.75 \text { i.u. })+\text { ovine } \\
\text { prolactin }(20 \mu \mathrm{g})+\mathrm{NRS}\end{array}$ & $\begin{array}{c}695 \cdot 79 \pm 19 \cdot 87 \\
(10)\end{array}$ & $\begin{array}{c}84 \cdot 56 \pm 2 \cdot 72^{\circ} \\
(10)\end{array}$ & $\begin{array}{c}83 \cdot 31 \pm 2 \cdot 69^{c} \\
(10)\end{array}$ & $36 \cdot 1+2 \cdot 2^{b}$ \\
\hline $\begin{array}{l}\text { HCG }(0.75 \text { i.u. }) \text { tovine } \\
\text { prolactin }(20 \mu \mathrm{g})+\text { anti- } \\
\text { serum to ovine prolactin } \\
(0.6 \mathrm{ml})\end{array}$ & $\begin{array}{c}727 \cdot 25 \\
(\overline{8})\end{array}$ & ${ }_{(\overline{8})}^{75 \cdot 99}+2 \cdot 82^{b}$ & $79 \cdot 14+\frac{1}{(8)} 1 \cdot 68^{c}$ & $\frac{28 \cdot 67}{(\overline{8})}$ \\
\hline
\end{tabular}

Values are Means \pm S.E.M. Figures in parentheses indicate the number of animals. NRS = normal rabbit serum. Within each column, values with different superscripts are significantly different, $P<0.05$.

The synergistic role of prolactin in the hormonal control of a number of target organs is becoming increasingly evident. Earlier studies have indicated that prolactin stimulates prostatic growth (Okamoto et al., 1967; Negro-Vilar et al., 1973) and increases the weight of the seminal vesicles (Chase et al., 1957; Antliff et al., 1960; Bengmark \& Hesselsjo, 1963, 1964; Dorfman, 1972; Negro-Vilar et al., 1973). These effects, however, were manifest only when prolactin was used with androgens. The results presented in this study indicate that ovine prolactin alone has no effect on any of the male accessory sex glands, but potentiates the action of HCG on the growth of the ventral prostate. We did not, however, notice a significant increase in the weights of the seminal vesicles. This corroborates the experimental findings of Okamoto et al. (1967), who demonstrated the lack of prolactin-androgen synergism on the growth of the seminal vesicles. Our results do not agree with those of Segaloff et al. (1956) who found a significant increase in the weights of the ventral prostate of hypophysectomized rats treated with 10.0 i.u. ( $350 \mu \mathrm{g}$ ) ovine prolactin, a dose at which there was synergism with ovine $L H$. The response given by 10.0 i.u. ovine prolactin was smaller to that induced by $120 \mu \mathrm{g}$ ovine $\mathrm{LH}$, but the degree of contamination of the prolactin with small amounts of LH was not determined. In the present study, the results of the bioimmunological experiments showed that antiserum to ovine prolactin suppressed the effects of ovine pro- 
lactin on the ventral prostate, and thus confirm the synergistic action of prolactin with HCG.

Ovine prolactin (NIH-P-S10) used in this study was a gift from the National Institute of Arthritis and Metabolic Diseases, National Institutes of Health, Bethesda.

\section{REFERENCES}

Antliff, H.R., Prasad, M.R.N. \& Meyer, R.K. (1960) Action of prolactin on seminal vesicles of guinea pig. Proc. Soc. exp. Biol. Med. 103, 77-80.

Bengmark, S.B. \& Hesselsjo, R.H. (1963) The combined effect of prolactin and androsterone on the growth of rat seminal vesicles in vitro. Urol. int. 16, 387-390.

Bengmark, S. B. \& Hesselsjo R.H. (1964) Endocrine dependence of rat seminal vesicle tissue in tissue culture. Urol. int. 17, 84-90.

Chase, M.D., Geschwind, I.I. \& Bern, H.A. (1957) Synergistic role of prolactin in response of male rat sex accessories to androgen. Proc. Soc. exp. Biol. Med. 94, 680-683.

Diczralusy, E. \& LoRArne, J.A. (1955) Sources of error in clinical bioassays of serum chorionic gonadotropin. 7. clin. Endocr. Metab. 15, 424-434.

DoRfMAN, R.I. (1972) Mechanism of action of gonadotropins and prolactin. In Biochemical Actions of Hormones, pp. 295-316. Ed. G. Litwack. Academic Press, New York.

GREEP, R.O., VANDYKe, H.B. \& Chow, B.F. (1941) Use of the anterior lobe of pituitary gland in the assay of Metakentrin. Proc. Soc. exp. Biol. Med. 64, 644-649.

Greep, R.O., VANDYKe, H.B. \& CHOw, B.F. (1942) Gonadotropins of the swine pituitary. Endocrinology 30, 635-649.

Negro-Vilar, A., Krulich, L. \& McCann, S.M. (1973) Changes in serum prolactin and gonadotropins during sexual development of the male rat. Endocrinology 93, 660-664.

Oкамото, R., KaWashima, K. \& Fujir, K. (1967) Action of prolactin on the male sexual organs of the rat. Bull. Tokyo med. dent. Univ. 14, 37. Cited by Dorfman (1972).

Purandare, T.V., Dattatreymurty, B., Munshi, S.R. \& RaO, S.S. (1975) Immunobiological actions of antiserum to ovine prolactin in mice. 7 . Reprod. Fert. 44, 411-419.

Segalorp, A., Steelman, S.L. \& Flores, A. (1956) Prolactin as a factor in the ventral prostate assay for luteinizing hormone. Endocrinology 59, 233-240.

Thakur, A.N., Sheth, A.R., Purandare, T.V., Munshi, S.R. \& Rao, S.S. (1975) Antisera to gonadotrophins and placental function in mice. I. Effect on polyamine content. F. Reprod. Fert. 43, 221224. 